\title{
ARTIFICIAL INTELLIGENCE AS A BASIS FOR THE DEVELOPMENT OF THE DIGITAL ECONOMY Textbook
}

\author{
Edited by \\ Irina Tatomyr \\ Drohobych State Pedagogical University after Ivan Franko (Ukraine)

\section{Zenovii Kvasnii} \\ Precarpathian Institute named of M. Hrushevsky of Interregional \\ Academy of Personnel Management (Ukraine)
}

eBook ISBN 978-80-88415-17-6

Print ISBN 978-80-88415-18-3 
Recommended for publication by the Precarpathian Institute named of M. Hrushevsky of Interregional Academy of Personnel Management (Protocol №10 dated 27.05.2021)

The work was performed within the research topic of the Mykhailo Hrushevsky Precarpathian Institute «Ukraine in the context of world and national modernization processes of statehood and civil society: political, legal, economic, social, psychological and administrative aspects» (Registration number 0119U100492. Date of registration - February 12, 2019)

\section{Reviewers:}

Levan Jakeli Professor, Dean of the Faculty of Law of Batumi State University. Sh. Rustaveli (Georgia)

Justyna Krzywkowska Doctor of Law, assistant professor Department of Legal Theory and History Faculty of Law and Administration University of Warmia and Mazury in Olsztyn (Poland)

Yeliseyeva Oksana Doctor of Economics, Professor, Head of the Department of Statistics, Accounting and Economic Informatics of Dnipro National University named after Oles Honchar (Ukraine)

\section{Editors:}

Irina Tatomyr PhD in Economics, Associate Professor

Zenovii Kvasnii Ph.D in Economics, Associate Professor

ARTIFICIAL INTELLIGENCE AS A BASIS FOR THE DEVELOPMENT OF THE DIGITAL ECONOMY: textbook; Edited by I. Tatomyr, Z. Kvasnii. Praha: OKTAN PRINT, 2021, $376 \mathrm{p}$.

No part of this eBook may be reproduced or transmitted in any form or by any means, electronic, mechanical, recording, or otherwise, without written consent from the Publisher

The publication is assigned with a DOI number: https://doi.org/10.46489/aiabftd-07

The paper version of the publication is the original version. The publication is available in electronic version on the website: https://www.oktanprint.cz/p/artificial-intelligence-as-abasis-for-the-development

Passed for printing 31.05.2021

Circulation 50 copies

Cover design: Irina Tatomyr

eBook ISBN 978-80-88415-17-6

Print ISBN 978-80-88415-18-3

OKTAN PRINT s.r.o.

5. května $1323 / 9$, Praha 4, 14000

www.oktanprint.cz

tel.: +420770626166

jako svou 59. publikací

Výdání první

(C) Copyright by OKTAN PRINT s.r.o., 2021 


\section{Contents}

\section{FEATURES OF FORMATION AND DEVELOPMENT OF ARTIFICIAL INTELLIGENCE}

1.1. Basic concepts of Artificial Intelligence ....................... Olha Pizhuk

1.2. History of Artificial intelligence ............................. 21 Olha Pizhuk

1.3. Attitude to artificial intelligence in society ..................... 31 Olha Pizhuk

1.4. Artificial intelligence and its possibilities

Irina Khmarska, Natalia Hryshyna, Natalia Mihai

\section{THE IMPACT OF ARTIFICIAL INTELLIGENCE ON CHANGING THE PROFILE OF THE LABOR MARKET}

2.1. Artificial intelligence as a factor of the global labor market transformation

Svitlana Tul, Olha Shkurupii

2.2. The need for the skills of the future

Artem Ahekyan, Rostyslav Peleschyshyn, Zenovii Kvasnii

2.3. Experience of leading countries in terms of density of robotics for the implementation of digital technologies

Liubov Kvasnii, Oksana Vivchar, Viktorija Paslavska, Liubov Malik 


\section{CHANGES IN THE FINANCIAL SERVICES MARKET UNDER THE INFLUENCE OF AI \\ Zoia Pestovska}

3.1. Artificial intelligence in banking .......................... 85

3.2. Artificial intelligence in insurance and financial technologies .... 97

3.3. Use of Artificial intelligence by financial institutions to increase business security and efficiency ........................... $\quad 110$

3.4. Artificial intelligence technologies in crisis management of banks 122

\section{ARTIFICIAL INTELLIGENCE AND THE FUTURE OF HEALTHCARE}

4.1. New systems of medical diagnostics

\section{Yurii Shulzhyk, Vadimir Mural, Oksana Kvasnii}

4.2. Labour and Social Protection problems in circumstances

of Artificial Intelligence's growing into Public Healthcare Sector ..

Viktoriia Viennikova, Ilya Kolosov

\section{THE IMPACT OF AI TECHNOLOGIES ON THE MODERNIZATION OF TRANSPORT INFRASTRUCTURE}

5.1. Artificial intelligence in industry 4.0 logistics and SUPPLY CHAINS

Elena Pryiatelchuk, Aleksey Stupnytskyy, Ivan Shved

5.2. Models of artificial intelligence of optimization and formation of logistics routes

Olena Chukurna, Liubov Bovnegra, Vitalii Dobrovolskyi

5.3. Artificial intelligence and the world market of self-driving vehicles

Elena Pryiatelchuk, Aleksey Stupnytskyy, Ivan Shved

\section{ARTIFICIAL INTELLIGENCE IN INDUSTRY AND ENERGY}

6.1. «Smart» industry ........................................ 200

Alfiia Antonova, Tatyana Snigur

6.2. European Smart Energy Policy .............................. 216

Iryna Marekha

\section{MANAGEMENT ASPECTS OF THE USE OF ARTIFICIAL INTELLIGENCE}

7.1. Conducting investment research and trading using artificial 
intelligence

Larysa Hryshyna, Liliya Filipishyna, Iryna Zhuvahina

7.2. Methods of constructing the recruitment process based on artificial intelligence

Svetlana Vovk, Valeriia Vashcenko, Tatyana Vovk

7.3. Artificial intelligence in $\mathrm{HR}$ - processes

Svetlana Rudakova, Nataliia Danylevych, Liudmyla

Shchetinina

7.4. Use of AI in accounting and auditing ...

Yuliya Manachynska

\section{ROADMAP FOR STRATEGIC CHANGES IN THE DIGITAL TRANSFORMATION OF NATIONAL ECONOMIC SYSTEMS}

8.1. Approaches to the development and implementation of road maps DX

\section{Oksana Kushnir}

8.2. Organizational and methodological support of digital transformation of national economic systems

Tetiana Marusei

8.3. Comparative analysis of state programs for the development of artificial intelligence.

Nataliia Mazur, Dariusz Nowak

8.4. Machine learning in engineering thermodynamics

Sergey Artemenko, Victor Mazur

\section{AI ON ENVIRONMENTAL PROTECTION}

9.1. Reasonable international technologies for environmental protection

Vira Tupychak, Marian Uniatytskyi

9.2. Methodology of application of artificial intelligence in cognition and management of economy ecologization

Viacheslav Stepanov

\section{THE USE OF ARTIFICIAL INTELLIGENCE IN RETAIL AND E-COMMERCE}

10.1. Transformation of the customer relationship management system in the digital economy

Aleksy Kwilinski, Mariia Hryhorak, Nataliia Trushkina

10.2. Digital marketing as an effective tool for improving the quality of customer service 
Aleksy Kwilinski, Yuliya Zaloznova, Nataliia Trushkina

10.3. E-commerce trends in the digital economy

Olesia Bezpartochna, Valentina Misyuckevich, Nataliia Trushkina 


\title{
II. ARTIFICIAL INTELLIGENCE AS A FACTOR OF THE GLOBAL LABOR MARKET TRANSFORMATION
}

\author{
Svitlana Tul \\ Ph.D. in Economics, \\ Associate Professor of the Department of International Economics and \\ International Economic Relations \\ Higher Educational Establishment of Ukoopspilka \\ "Poltava University of Economics and Trade" \\ E-mail: tulsvetlana@ukr.net \\ ORCID ID: 0000-0003-3637-4197 \\ Olha Shkurupii \\ Doctor of Sciences (Economics), \\ Professor of the Department of Economics and International Economic Relations \\ Poltava State Agrarian Academy \\ E-mail: olga.sh0123@gmail.com \\ ORCID ID: 0000-0002-5818-7651
}

The modern period of human life can reasonably be determined as the beginning of the post-industrial era because its formation is potentiated by the Fourth Industrial Revolution. Klaus Schwab (2016), studying the process of the deployment of the Fourth Industrial Revolution, notes a number of changes that have become significant for humanity now and will remain significant for many future generations. He indicates the exponential (in speed, scale and impact) growth of innovation, which leads to increased efficiency, productivity and cost reduction in production, as well as an extraordinary increase in data sets and opportunities for their use. All this is accompanied by the implementation of a new generation of technologies based on artificial intelligence, the importance of which can be traced from mass robotization to biotechnology.

According to analysts (Lane \& Saint-Martin, 2021), artificial intelligence will have a strong impact on the transformation of the labor market. The number of intelligently equipped devices, applications and interconnected systems is growing significantly today and will continue to grow in the future. In combination with other new technologies, artificial intelligence is becoming the driving force of the Fourth Industrial Revolution. This is primarily due to the spread of its use in all spheres of human life.

Olha Pyshchulina (2020) considers digitalization and the creation of artificial intelligence to be the new growth driver after the era of the computer revolution. The McKinsey Global Institute predicts the digital economy will reach its maximum level of development by 2030 . By this time, as a result of the active use of artificial intelligence, global GDP, according to the findings of PricewaterhouseCoopers (PwC, 2019), will grow by $14 \%$; that is, almost USD 16 
trillion.

Noting the role of digital technologies, robotics, artificial intelligence, and other breakthrough innovations, it should be emphasized that the basis of these changes is human labor. Human intelligence and creativity became the source of the modeled ability of artificially created systems to act and make decisions like an individual. Compared to this, artificial intelligence, even extremely perfect, will still remain a derivative of human activity.

The use of digital technologies predetermines labor efficiency while reducing the workload per employee. It should be noted the importance of artificial intelligence, with the use of which there are ample opportunities to operate with large amounts of information, which facilitates decision-making in production, business, scientific and research activities. According to the forecast of the World Economic Forum (WEF, 2018), the share of machines and algorithms in working hours will be $42 \%$ in 2022 . Robots with integrated artificial intelligence will do more and more work for humans, but they will be able to perform only part of the tasks. According to experts, only a quarter of workplaces can be automated by over $70 \%$. Automation rates may vary depending on the industry and the sphere of economic activity. For example, about $47 \%$ of all processes in information and data processing are currently automated, projected that by 2022 the automation of this activity will be $62 \%$, however in reasoning and decision-making - only $19 \%$, by 2022 it will be $28 \%$ (Table 3 ).

Table 3

Projected automation rates in $\mathbf{2 0 2 2}$

\begin{tabular}{|l|c|c|}
\hline \multirow{2}{*}{ Activity } & \multicolumn{2}{c|}{ Ratio of human-machine working hours, \% } \\
\cline { 2 - 3 } & Human & Machine \\
\hline Reasoning and decision-making & 72 & 28 \\
\hline $\begin{array}{l}\text { Coordinating, developing, managing and } \\
\text { advising }\end{array}$ & 71 & 29 \\
\hline Communicating and interacting & 69 & 31 \\
\hline Administering & 56 & 44 \\
\hline Performing physical and manual work activities & 56 & 44 \\
\hline $\begin{array}{l}\text { Identifying and evaluating job-relevant } \\
\text { information }\end{array}$ & 54 & 46 \\
\hline Performing complex and technical activities & 54 & 46 \\
\hline $\begin{array}{l}\text { Looking for and receiving job-related } \\
\text { information }\end{array}$ & 45 & 55 \\
\hline Information and data processing & 38 & 62 \\
\hline
\end{tabular}

Source: Developed by authors based on the Future of Jobs Report (2018).

The development of technologies reduces the working hours that people spend producing goods or providing services. However, this does not mean that robotization, which in the post-industrial perspective is likely to become almost all-encompassing, will provoke fatal consequences in the form of technological unemployment, since only routine tasks are being automated. Moreover, the emergence of new technologies can lead to an increase in the demand for workers 
with new competencies. Creativity, research and invention acquire special value in modern society. Therefore, people will concentrate on intellectual work providing unique and customized services. The COVID-19 pandemic has accelerated the transformation of the labor market and transition to new jobs. According to the post-COVID-19 scenario of the McKinsey Global Institute (Lund et al., 2021), 100 million workers ( 1 in 16) from examined countries (China, India, United States, Germany, Japan, United Kingdom, France and Spain) will change their job by 2030.

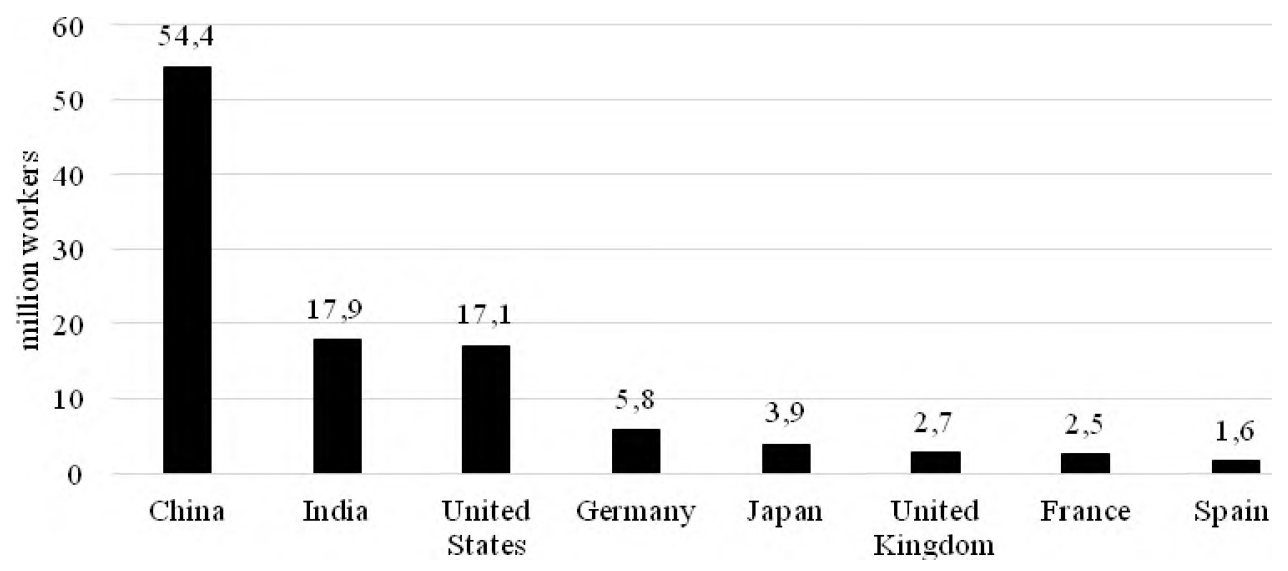

Figure 13. Job transitions in different countries by 2030, million workers (2021).

Source: Developed by authors based on the Future of Work after COVID-19 Report

Digitalization processes affect the emergence of new professions not only in the IT sector but also have a significant impact on sectoral changes in the world labor market as a whole. For instance, the banking and financial sector is undergoing significant changes under the influence of processes of automation, robotization, and the use of artificial intelligence. In the near future, in the banking and financial sector, there will be a decrease in the number of employees with basic skills (the ability to count, data entry into accounting systems and their processing), while the demand for employees with high-tech skills (software development for financial transactions) and social-emotional skills (customer orientation) will grow. The spread of digital technologies has a significant impact on the transformation of the retail industry: automated self-service systems are replacing cashiers, robotic technology performs the work of loaders, machine learning allows predicting consumer demand for goods and services. Therefore, in the near future, there will be a decrease in the number of employees who are responsible for weighing, warehousing, loading or unloading goods.

Researchers (Herweijer \& Waughray, 2018) prove that by 2030 the further development of artificial intelligence and other technologies of the Fourth Industrial Revolution can bring innovations such as a digital geospatial dashboard for the planet, an autonomous farming and end-to-end optimized food system, a home supercomputer and artificial intelligence-based research assistants, quantum and distributed computing that can significantly increase the computing power of 
artificial intelligence. However, even with an extremely high level of development of these technologies, as well as those of which we now do not even know, intellectual activity will always be inherent only in humans. Therefore, nowadays, the main task for resolving the "human / machine" contradiction is not their opposition, but the mutual supplement of human intelligence with artificial and vice versa.

New technological advances in areas such as artificial intelligence, robotics, the Internet of Things, augmented and virtual reality influence the formation of the concept of the global labor market. Researchers from the McKinsey Global Institute (Farrell et al., 2005) consider the global labor market as the process of global recruitment of labor that involves the formation of real demand and supply for remote work through offshoring. International Labour Organization experts (Kuptsch et al., 2010), examining the trends in the formation of the global labor market, note that nowadays there is a process of internationalization of national labor markets, namely the formation of cross-border supply and demand for labor. Richard B. Freeman (2008) and Niels Beerepoot (2014) define the global labor market as a global Internet job market, which forms international competition between workers for a vacancy.

Taking into account the achievements of the modern theory of international economic relations, Ukrainian scientists pay considerable attention to the problem of the formation of the global labor market. Yaroslava Stolyarchuk and Svitlana Poruchnyk (2014) contemplate the term "global labor market" as "a system of relations concerning the coordination of supply and demand of labor, regulation of its interstate flows, wages and social security". According to the study of Anatoliy Kolot (2018), the global labor market is formed under the influence of "large-scale changes in the social division of labor, unprecedented mobility of production, the washing out of jobs in some countries and the creation of a new job market in others, depending on changes in the structure and scale of international trade".

In our opinion, the global labor market correlates directly with the spread of digitalization and the formation of the digital economy that provides the conditions for the integrity of the space of modern labor relations on the indicated (global) scale. A new phenomenon is acquiring special significance in the digital economy - the digitalization of the global labor market. The development of digital technologies directly affects the quality of life, the economic efficiency of business and the state, and also contributes to the emergence of new forms of work. The digitalization of business operations "blurs" the geographical borders between countries and creates a single digitalized global labor market in the modern world.

Nowadays, the labor market is acquiring global characteristics, while remaining heterogeneous and contradictory. There are several trends that indicate the formation of the global labor market: 1) the interdependence of national economies contributes to the formation of an integral system of interacting national labor markets; 2) spreading Internet access in different countries leads to the development of the global digital market; 3) expanding the influence of digital companies that generate new jobs all over the world; 4) the systematic movement 
of highly skilled labor to countries with a high level of digitalization, which leads to a deepening of technological specialization on a global scale; 5) changes in the qualitative characteristics of the labor market (increasing requirements for the level of education and qualification); 6) the rapprochement of cultures in the process of transformation of the structure of values and social norms of workers of generation "Y" and "Z"; 7) changing the work-life balance leads to the emergence of new forms of employment; 8) increase in the number of global digital labor platforms that facilitate interstate operations in the field of employment.

In the context of the evolution of socio-economic systems, the following structural transformations of the global labor market are observed:

1. The reconfiguration of the boundaries of the traditional division of labor. New professions are emerging at the request of the digitalization of economic sectors. For example, a manager of crowdfunding and crowdinvesting platforms appears in finance; an operator of automated transport systems - in logistics; a medical data manager - in healthcare, etc. A contradiction arises between the rigid consolidation of functions in a particular profession (according to the International Standard Classification of Occupations), on the one hand, and the dynamics and flexibility of the social and labor sphere, on the other hand. The introduction of artificial intelligence, robotization and automation of the production process radically change the essence of labor in all industries and form new requirements for the competencies of workers. Narrow professional training is being replaced by the need to form cross-cutting competencies (communication skills, critical thinking, digital literacy), the importance of which is growing every year.

2. Changing the ways and forms of employment. Along with the traditional contractual forms of implementation of labor relations, employment is actively developing in terms of freelancing, outsourcing and crowdsourcing (OECD, 2016).

3. Increasing human mobility. This is due to both the intensification of migration processes and interprofessional, interbranch, intrafirm mobility. Lifelong learning as a principle and concept is increasingly being developed and implemented in practice. The situation is becoming more and more common when a person changes his / her professional affiliation throughout his / her working life.

4. Creating jobs for the employee's tasks and competencies, customer requests and technology. As a result, there is a need for such a mechanism that would allow, in conditions of exponential changes, to carry out in advance the connection between technological change and transformations in the division of labor.

5. The priority of human talent over the capital in the system of factors of production. In the context of the gradual digitalization of the global economy, talent, rather than capital, is becoming the most important factor of production, which leads to the transformation of the labor market, within which the segments of "low skills -low wages" and "high skills - high wages" are formed.

Under the influence of these trends, the system of the global labor market is gradually being formed. It is characterized by a specific culture and institutions that have arisen as a result of the intertwining and interpenetration of various 
national organizational and business cultures, which are embedded in the created global institutions and manifest themselves in a new quality. At the macroeconomic level, supply and demand for labor depend on the dynamics of the national and international markets, as well as factors such as immigration, age, level of education.

Digitalization is an important factor in the formation of the digital ecosystem of the global labor market, which is a structural element of the global market ecosystem. The digital ecosystem of the global labor market should be understood as a system of digitalized relationships between representatives of international business and the economically active population of different countries regarding the buying and selling of labor, which is formed within the framework of scientific and educational and digital spaces and is coordinated by national governmental and non-governmental organizations, regional organizations and associations, international intergovernmental and non-governmental organizations (Tul \& Shkurupii, 2020). The mechanism of the functioning of the global digitalized labor market is distinguished by the fact that the intermediate states of the buying and selling relationship and current processes take place within the global digital ecosystem. The mechanism of the functioning of the global digitalized labor market is a complex system of distribution of labor among the sectors of the world economy through digitalized labor relations (from hiring workers to paying wages), which are coordinated by socially created institutions of market regulation and the institution of market self-regulation. Within the framework of the concept of a global digital ecosystem, it is considered with an emphasis on the specifics of three-tier (macro-, meta- and mega-) regulation and the presence of a special infrastructure (Figure 14).

According to our proposed model, the mechanism of the functioning of the global digitalized labor market is formed by:

1) the global ecosystem of employers is a network of business entities of various organizational forms that operate in five sectors of the world economy and interact through the use of digital tools. The division of the economy by sectors is as follows: primary sector - agriculture and extractive industries; secondary manufacturing; tertiary - transport and utilities; quaternary - trade, finance, insurance and real estate; quinary - healthcare, education, recreation, governmental services and research;

2) the global ecosystem of employees is a global pool of workers with different qualification (highly skilled, skilled, low-skilled) belonging to different professional, age, racial, socio-cultural groups and performing work on a regular or non-regular basis;

3) scientific and educational space is a community of leading educational institutions, business schools, training centers, distance learning platforms, research institutions from around the world that form a digital environment for lifelong learning; 
4) digital space is an environment consisting of IT infrastructure, digital interfaces, as well as digital technologies and determines digital interaction between business, employees, the scientific and educational community, a network of national, regional, international regulatory bodies.

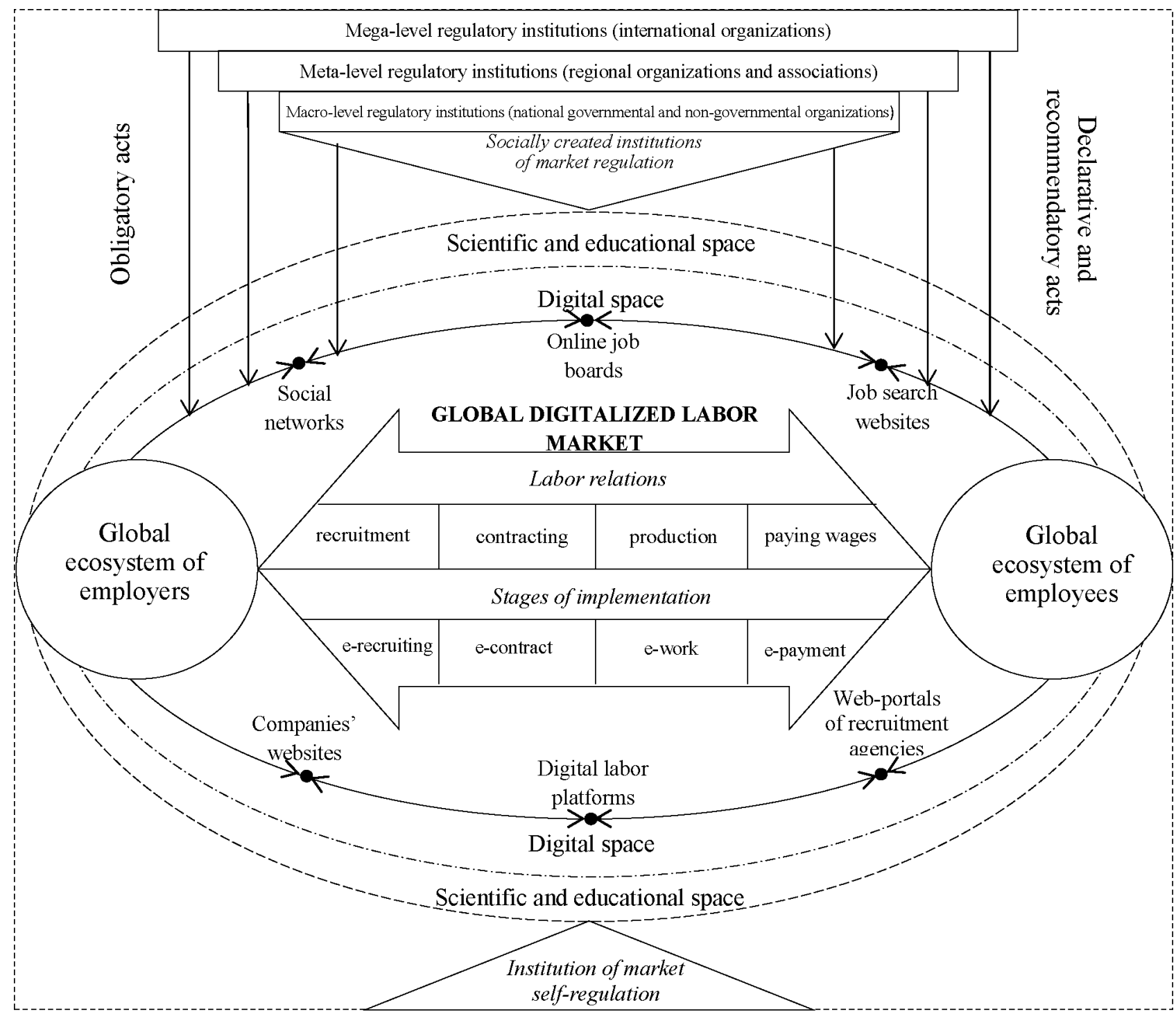

Figure 14. The mechanism of the functioning of the global digitalized labor market

Source: Developed by authors

Regulation and coordination of the digital ecosystem of the global labor market is carried out through socially created institutions of market regulation at three levels (macro-, meta- and mega-) through the development of obligatory acts (conventions, pacts, protocols) and declarative and recommendatory acts (recommendations, declarations, consulting documents).

The regulatory institution of the mega-level is the UN specialized agency the International Labour Organization (ILO). Its main task is to promote social progress, to establish and maintain social peace between different strata of society, 
as well as to solve arising social problems in an evolutionary and peaceful way. Therefore, membership in the ILO requires states to monitor compliance with fundamental principles in the field of labor relations: the freedom of association and the right to collective bargaining; the prohibition of discrimination in labor relations; the elimination of forced labor; the prohibition of child labor. In order to address the challenges associated with profound changes in the world of work, the ILO Global Commission on the Future of Work was established in 2017. The main task of this organization is to develop comprehensive measures to ensure: 1) the general labor guarantee; 2) the guaranteed social protection from birth to old age; 3 ) the general right to lifelong learning, which gives people the opportunity to acquire professional skills and improve their qualifications; 4) the principles of gender equality. Moreover, the main task of this institution is to use the results of technological progress in the interests of ensuring decent work, including the development of an international system for digital labor platforms regulating.

The regulatory institutions of the meta-level are regional organizations and associations. The level of meta-regulation involves the coordination of aspects of social and labor relations that arise between business representatives and the labor force within geographic and geopolitical boundaries. To address the specific challenges of regional labor markets, the ILO established the International Labour Office with regional offices in Africa, Latin America and the Caribbean, the Middle East, Asia Pacific, Europe and Central Asia.

At the macro-level, the coordination of labor relations is carried out by national governments and authorities, which form the legislation that regulates the relationship between employers and employees. State regulation of the labor market is implemented as follows: 1) the approval of legislative norms governing the procedure for hiring and firing, the rights and obligations of the employer and the employee and establishing responsibility for violation and non-compliance with these norms; 2) the development and implementation of employment policy, social protection of employees who temporarily lost their jobs, lifelong learning, etc. Non-governmental organizations that provide consulting and expert services to representatives of these ecosystems are also considered macro-level regulatory institutions. Nowadays, the most influential organizations in the labor market are the national non-governmental organizations of the USA and the EU: Freelancers Union, Service Employees International Union, European Forum of Independent Professionals, etc.

The functioning of the digital ecosystem of the global labor market is ensured by the institution of market self-regulation, which is based on a mechanism for balancing the main elements of the labor market: demand in the form of the needs of companies in the labor; supply in the form of labor resources of the economically active population; labor prices in the form of wages; competition between employees for a vacancy, and between employers for the ability to attract labor in the required quantity and with the required skills. The digitalization of labor relations between an employee and an employer takes place according to the scheme "e-recruiting - e-contract - e-work - e-payment". The 
main digital channels through which the mechanism of self-regulation of the labor market is indirectly carried out are digital labor platforms, online job boards, job search websites, web-portals of recruitment agencies, companies' websites, social networks.

Within the digital ecosystem of the global labor market, a global digitalized labor market is being formed. Digitalization of the labor market is a new phenomenon in the world economy, which provides for an exponential growth in the number of digital labor platforms that form a single global labor market.

The global digitalized labor market should be viewed as a global integrated digital space, within which the interaction of labor buyers and sellers is realized through functioning of the interstate mechanism of supply and demand regulation using digital labor platforms, online job boards, job search websites, web-portals of recruitment agencies, companies' websites and social networks. The relationship between the players of the global digital labor market is maintained through crossborder transactions, information exchange and modern technology.

The global digitalized labor market has the following features: 1) growth in the volume of work performed through the use of digital technologies; 2) an increase in the number of digital labor platforms (intermediaries between employees and employers); 3) growth in the total number of independent selfemployed freelance professionals; 4) spread of new forms of work based on temporary employment contracts, zero-hour contracts (an employment contract under which the employer does not guarantee the employee daily employment and pays only the hours actually worked), umbrella contracts (an employment contract consisting of a number of individual contracts); 5) spread of crowdsourcing (attracting a "smart crowd" to jointly search for effective business solutions).

The formation of a single digitalized labor market gives any business access to a large number of mobile labor force with specific skills to solve urgent problems. Digitalized work involves the performance of various types of work by an employee remotely from the employer's location using digital technologies and mobile applications via digital labor platforms ("Fiverr", "Upwork", "Freelancer", "PeoplePerHour", etc.). According to the World Employment and Social Outlook 2021 (ILO, 2021), multinational corporations turn to freelance professionals through a range of digital labor platforms, which simplifies and speeds up the process of finding the required pool of highly qualified personnel.

Digital labor platforms ensure the functioning of the global labor market. These platforms reduce the time and financial resources required to find highly qualified personnel of a certain (sometimes unique) specialization and also create opportunities for the realization of knowledge, skills and abilities by independent self-employed professionals in the field in which they are competent. The digital economy is characterized by rapid growth rates and therefore there is a need to analyze the effectiveness of the functioning of digital labor platforms and the role of self-employed independent professionals working in this sector.

Nowadays, digital labor platforms are becoming efficient information and analytical centers. They can be classified in three areas: 1) platforms that allow one 
to find a job or employees ("LinkedIn", "Monster.com", "Vault.com", "Indeed", "Careerbuilder", "Xing", "Glassdoor"); 2) platforms where service providers cooperate with their customers ("Uber", "TaskRabbit", "Angie's List", "Upwork", "Amazon Home Services"); 3) platforms for talent and performance management ("Good.co", "PayScale", "Reviewsnap", "Pymetrics"). According to the forecasts of the McKinsey Global Institute (Manyika et al., 2015), by 2025 digital labor platforms will provide 72 million full-time jobs, which will ensure the growth of world GDP by USD 2.7 trillion (or $2 \%$ ). Until 2025, 540 million economically active people around the world will be able to benefit from the activities of digital labor platforms. Thus, 230 million people will shorten their period of unemployment, quickly gaining new jobs; 200 million people who don't work or work part-time will find additional work through the freelance platforms; 60 million people will have the opportunity to find a job that directly meets their skills; another 50 million people will move from informal to formal employment.

Digital labor platforms reflect the real situation in the labor market since they affect the transparency of the demand that exists for certain professional skills. This makes it possible to make guidelines for young people in choosing such a type of educational program that will clearly meet the requirements of the labor market. As a result, there is a possibility to reduce irrational spending on higher education. In different countries, where there is a mismatch between supply and demand for a number of professions, such costs are estimated by experts at USD 89 billion. Digital labor platforms ensure efficient use of labor. Small businesses or startups that are the main customers of these platforms can outsource certain types of work to self-employed professionals. This allows small and medium-sized businesses to gain access to employees with specialized skills, for example, in developing applications for mobile devices, user interface design, search engine optimization paying only for the amount of work performed. According to the McKinsey Global Institute (Manyika et al., 2015), companies that are clients of digital labor platforms have seen an increase in labor productivity by $9 \%$ and a decrease in the cost of attracting highly qualified personnel by $7 \%$.

Digital labor platforms contribute to the growth of employment of the population and increase the wages of independent self-employed professionals by creating equal working conditions. In the digital economy, the uniqueness of knowledge and skills is becoming a key factor influencing the formation of wages. For example, according to the Freelance Forward 2020 Report (Upwork, 2020), 59 million American freelancers earned USD 1.2 trillion in 2020. The most common digital labor platforms as of 2021 are "Fiverr", "Upwork", "Freelancer.com", "Envato Studio", "CrewScale", "PeoplePerHour", "Toptal", "Guru.com", "DesignCrowd", "Nexxt" (Table 4).

In addition, digital labor platforms are becoming a place for the concentration of international capital. The functioning of these platforms simplifies and accelerates the procedure of financial transactions between buyers and sellers of services through the use of modern electronic payment systems (PayPal, Skrill, Payoneer, WebMoney). 
General vector and sectoral changes in the global economy are a reflection of structural changes taking place within the framework of the systemic transformation of society. The criterion for such changes is the spread of artificial intelligence and the digitalization of human activities. Thus, a new phenomenon, which is the digitalization of the labor market, is acquiring special significance in the digital economy. It has been proven that the transformation of the labor market presupposes a rapid increase in the number of digital labor platforms that form a single global labor market. In the digital economy, there has been a significant increase in the number of independent self-employed professionals who perform various types of work remotely from the employer's location using digital technologies through digital labor platforms. A number of factors accelerate the development of digital labor platforms, namely socio-demographic shifts, the growth of international trade, the spread of information and communication technologies.

Rating of the top 10 digital labor platforms according to the

Table 4 "FinancesOnline.com", 2021

\begin{tabular}{|c|l|l|c|}
\hline Rank & $\begin{array}{c}\text { Digital labor } \\
\text { platform }\end{array}$ & \multicolumn{1}{|c|}{ Type of platform } & Headquarters \\
\hline 1 & Fiverr & Freelance marketplace, online outsourcing & Israel \\
\hline 2 & Upwork & Freelance marketplace & USA \\
\hline 3 & Freelancer.com & Freelance marketplace & Australia \\
\hline 4 & Envato Studio & Freelancing website & Australia \\
\hline 5 & CrewScale & Platform for building tech teams & UKA \\
\hline 6 & PeoplePerHour & Freelance service marketplace & USA \\
\hline 7 & Toptal & Freelance marketplace & USA \\
\hline 8 & Guru.com & Freelance marketplace & Australia \\
\hline 9 & DesignCrowd & Online crowdsourcing platform & USA \\
\hline 10 & Nexxt & Cloud-based freelance platform & . \\
\hline
\end{tabular}

Source: Developed by authors based on FinancesOnline.com data (2021).

The single digitalized labor market, which is being actively formed, has positive economic and socio-demographic effects on modern society. The economic effect is manifested, first of all, as a reduction in time and resources (including human and financial). In particular, business by reducing the time and funds for finding highly qualified personnel of unique specialization ensures its effectiveness. The socio-demographic effect is manifested in the realization of the intellectual potential of independent self-employed professionals, regardless of their place of residence. Moreover, the digitalization of the global labor market makes it possible to solve a number of socially significant problems, namely reducing unemployment, especially among young people, creating jobs, reducing social tensions in depressed regions around the world.

\section{REFERENCES}

1. Schwab K. (2016). The Fourth Industrial Revolution: what it means, how to respond. World Economic Forum. Retrieved from: 
https://www.weforum.org/agenda/2016/01/the-fourth-industrial-revolution-what-itmeans-and-how-to-respond (Last accessed: 03.05.2021)

2. Lane M., \& Saint-Martin A. (2021). The impact of Artificial Intelligence on the labour market: What do we know so far? OECD Social, Employment and Migration Working Papers, No. 256, OECD Publishing, Paris, 60 p. DOI: https://doi.org/10.1787/7c895724-en

3. Pyshchulina O. (2020). Tsyfrova ekonomika: trendy, ryzyky ta sotsialni determinant [Digital economy: trends, risks and social determinants]. Kyiv : Tsentr Razumkova, Vydavnytstvo «Zapovit», 274 p. Retrieved from: https://razumkov.org.ua/uploads/article/2020_digitalization.pdf (Last accessed: 03.05.2021)

4. PwC (2019). 2019 AI Predictions. Six AI priorities you can't afford to ignore. Retrieved from: https://www.pwc.com/us/en/services/consulting/library /artificial-intelligence-predictions-2019.html (Last accessed: 04.05.2021)

5. WEF (2018). The Future of Jobs Report 2018. Geneva: World Economic Forum, 133 p. Retrieved from: http://www3.weforum.org/docs/ WEF_Future_of_Jobs_2018.pdf(Last accessed: 04.05.2021)

6. Lund S., Madgavkar A., Manyika J., Smit S., Ellingrud K., Meaney M., \& Robinson O. (2021). The future of work after COVID-19. McKinsey Global Institute. Retrieved from: https://www.mckinsey.com/featured-insights/future-ofwork/the-future-of-work-after-covid-19 (Last accessed: 04.05.2021)

7. Herweijer C., \& Waughray D. (2018). Fourth Industrial Revolution for the Earth. Harnessing Artificial Intelligence for the Earth. PwC, 48 p. Retrieved from: https://www.pwc.com/gx/en/news-room/docs/ai-for-the-earth.pdf (Last accessed: 05.05.2021)

8. Farrell D., Laboissiere M., Pascal R., Segundo C., Rosenfeld J., Stürze S., \& Umezawa F. (2005). The emerging global labor market. McKinsey Global Institute. Retrieved from: https://www.mckinsey.com/featured-insights/ employment-and-growth/the-emerging-global-labor-market (Last accessed: 06.05.2021)

9. Kuptsch C. (ed.) (2010). The internationalization of labour markets. Geneva : International Labour Organization, 229 p. Retrieved from: http://citeseerx.ist.psu.edu/viewdoc/download?rep=rep1\&type=pdf\&doi=10.1.1.18 8.961 (Last accessed: 06.05.2021)

10. Freeman B. R. (2008). The new global labor market. Focus, Vol. 26, № 1, 1-6. Retrieved from: https://www.irp.wisc.edu/publications/focus /pdfs/foc261.pdf (Last accessed: 06.05.2021)

11. Beerepoot N. (2014). Creating a global labour market. The opportunities and challenges of outsourcing and reshoring. The Broker. Retrieved from: https://www.thebrokeronline.eu/creating-a-global-labour-market-d93/ (Last accessed: 06.05.2021)

12. Stoliarchuk Ya., \& Poruchnyk S. (2014). Suchasna sehmentatsiia ta kliuchovi tendentsii rozvytku svitovoho rynku pratsi [Modern segmentation and key trends in the development of the world labor market]. Ukraina: aspekty pratsi, 
7, 12-17. Retrieved from: http://nbuv.gov.ua/UJRN/Uap_2014_7_4 (Last accessed: 06.05.2021)

13. Kolot A. M. (2018). Sotsialno-trudova sfera v koordynatakh novoi ekonomiky: rozshyrennia mozhlyvostei ta novi zahrozy [Social and labor sphere in the coordinates of the new economy: expansion of opportunities and new threats]. Sotsialno-trudova sfera $v$ umovakh stanovlennia novoi ekonomiky: hlobalni vyklyky ta dominanty rozvytku: materialy kruhloho stolu. Kyiv: KNEU, 7-15. Retrieved from: http://ir.kneu.edu.ua/bitstream/handle/2010/25195/KS.pdf;jsessionid=016822137C 91AF36930E42F5F3BFF617? sequence $=1$ (Last accessed: 06.05.2021)

14. OECD (2016). New Forms of Work in the Digital Economy. OECD Digital Economy Papers, No. 260, OECD Publishing, Paris, 44 p. DOI: https://doi.org/10.1787/5jlwnklt820x-en

15. Tul S., \& Shkurupii O. (2020). Didzhytalizatsiia svitovoho rynku pratsi [Digitalization of the world labor market]: monograph. Poltava: PUET, $302 \mathrm{p}$.

16. ILO (2021). World Employment and Social Outlook 2021: The role of digital labour platforms in transforming the world of work. Geneva: ILO, $282 \mathrm{p}$. Retrieved from: https://www.ilo.org/wcmsp5/groups/public/---dgreports/--dcomm/---publ/documents/publication/wcms_771749.pdf (Last accessed: 07.05.2021)

17. Manyika J., Lund S., Robinson K., Valentino J., \& Dobbs R. (2015). A labor market that works: connecting talent with opportunity in the digital age. New York : McKinsey Global Institute, 88 p. Retrieved from: https://www.mckinsey.com/ /media/mckinsey/featured\%20insights/employment $\%$ 20 and $\% 20$ growth/connecting $\% 20$ talent $\% 20$ with $\% 20$ opportunity $\% 20$ in $\% 20$ the $\% 2$ 0digital\%20age/mgi_online_talent_a labor_market_that_works_full_report_june 2015.pdf (Last accessed: 07.05.2021)

18. Upwork (2020). Freelance Forward 2020, 89 p. Retrieved from: https://www.upwork.com/documents/freelance-forward-2020 (Last accessed: 07.05.2021)

19. FinancesOnline (2021). 20 Best Freelance Websites for Beginners and Professionals in 2021. Financesonline.com. Retrieved from: https://financesonline.com/top-20-freelance-websites-for-beginners-andprofessionals/ (Last accessed: 07.05.2021) 